\title{
Modeling of a hybrid energy system, Photovoltaic and Generator (PV/GE) at the Higher Institute of Technology of Mamou, Guinea
}

\author{
Ansoumane Sakouvogui ${ }^{1,{ }^{*}}$, Amadou Diarra ${ }^{2}$, Faya Oulare ${ }^{3}$, Elhadj Ousmane Camara ${ }^{1}$, \\ Saïdou Barry ${ }^{1}$, Mamby Keita ${ }^{4}$ \\ ${ }^{1}$ Department of Energy, Higher Institute of Technology of Mamou, Guinea. \\ 2 Department of Mechanical Engineering, Gamal Abdel Nasser University of Conakry, Guinea \\ ${ }^{3}$ Department of Physics, Faculty of Natural Sciences, Julius Nyéréré University of Kankan, Guinea. \\ ${ }^{4}$ Department of Physics, Gamal Abdel Nasser University of Conakry, Guinea. \\ * Corresponding author email: ansoumane2015@gmail.com \\ DOI: https://doi.org/10.34256/irjmt2142 \\ Received: 13-04-2021, Revised: 22-05-2021, Accepted: 05-06-2021, Published: 08-06-2021
}

Abstract: This present work was carried out at the Energy Department of the Higher Institute of Technology of Mamou and at the Applied Energy Education and Research Laboratory of the Faculty of Sciences of the Gamal Abdel Nasser University of Conakry, Guinea. Given the solar energy potential available to the continent, Hybrid Photovoltaic Power Systems and Generating Sets could constitute a suitable technological solution for the supply of electrical energy in isolated sites. This study led to the following results: average unfavorable solar irradiation in June (4.16 $\mathrm{kWh} / \mathrm{m} 2 . \mathrm{d}$ ); the building's electrical load balance is $254760 \mathrm{Wh} / \mathrm{d}$; the sizing of the photovoltaic field (the type of panels chosen Cip-60-270, the peak power of the PV field $59435.420 \mathrm{Wp}$, the number of panels 220 including 2 in series and 110 in parallel); the C4000-48 type inverter-chargers, 62 in number to achieve a power of 40 nickelcadmium $1.2 \mathrm{~V}$ type accumulators in series in 140 batteries connected in parallel, the voltage drop in the cables is between 0.01 and 0.02 . The electrical diagram of the installation is done.

Keywords: Solar panel, Photovoltaic, Battery, Inverter, Regulator

\section{Introduction}

Access to electrical energy is the key to any economic development. However, the countries of SubSaharan Africa have a low rate of access to electricity; the situation is even more exacerbated in the rural areas of these countries [1]. Most of the countries of subSaharan Africa, Guinea in particular, still have a low rate of access to electricity at $27 \%$. The consumption of electrical energy is preceded by production, transmission and distribution to consumers, which represents a financial burden for the electrification of isolated sites. Paradoxically, Africa has an enormous energy potential that is very little exploited: the sun $(74 \%$ of the continent receives an average annual sunshine greater than $1900 \mathrm{kWh} / \mathrm{m}^{2} /$ year), which favors the development of solar energy systems in these areas regions [2]. Backup systems (generators, energy accumulators) are always essential, because of the disturbances due to the high variability in user demand for the low-voltage electricity network. To date, the techniques developed according to the places of use and the power demanded offer the possibility of combining several energy production systems (hybrid systems). These new technologies have the advantage of being able to supply electricity to both isolated local networks and the existing network. The hybridization of energy production sources can present itself as a rational energy alternative to conventional sources for the electrification of rural and isolated areas [3]. The Republic of Guinea has a great energy potential from various sources (biomass, hydroelectric, solar, wind and thermal), with $6000 \mathrm{MW}$ hydroelectric, an average solar irradiation of 4.8 $\mathrm{kWh} / \mathrm{m}^{2} . \mathrm{d}$, an average wind speed varying between 2 to $4 \mathrm{~m} / \mathrm{s}$ and biomass 612,000 toe.

However, the demand for electrical energy is still a concern, with consumption of 0.5 toe/year per capita [4]. With an abundant potential that is still underexploited, photovoltaic are economically and environmentally beneficial. However, its intermittent 
nature decreases its energy efficiency when operated alone. The use of hybrid (multi-source) systems combining thermal and renewable energy sources is generally considered by all as the solution of the future, both efficient and reliable [5]. Over the past 10 years, a lot of research has been done on the modeling, design, optimization, and control and monitoring of hybrid energy systems. Research and development efforts in the technology of these energy systems must continue in order to improve their performance and reliability.

A Hybrid Energy System is a system that combines at least two complementary technologies: one or more conventional energy sources, usually diesel generators, and at least one renewable energy source [6].

Hybrid renewable energy systems must include at least one energy storage system to meet the demand of the loads at all times. The energy storage system can be a battery bank, an assembly electrolyze and fuel cell, a super capacitor, or a combination of these storage systems [7-11]. Several parameters go into the study of hybrid systems, sizing is the first considered, although in the literature it is difficult to find how to size the different components of an autonomous system. Most of the works focus on the basic theories of technologies, but rarely on the precise sizing of basic equipment (eg solar panels, wind turbines or generators) [12]. The general objective of this work is to model a photovoltaic hybrid energy system/generator set at the Higher Institute of Technology in Mamou.

\section{Materials and Methods}

\subsection{Presentation of the site}

The present study concerns one of the buildings of the Higher Institute of Technology of Mamou, it is located between $10^{\circ} 21^{\prime}$ North latitude and $12^{\circ} 06^{\prime}$ South longitude, in the Teliko district $4 \mathrm{~km}$ from the city center town of Mamou [13]. The Higher Institute of Technology of Mamou is a public higher education establishment of a technical, educational, technological and scientific nature. The building covered by this study is built on an area of $360 \mathrm{~m}^{2}$, with two (2) classrooms, a computer room, two (2) offices and a terrace (Figure 1.a and 1b).

\subsection{Materials and working hypotheses}

During this study we used electrical measuring devices, work equipment, software, data sheets, manuals and installation diagrams. The assumptions are as follows: (I) low power receivers (lamps, computers, printers) are supplied by the photovoltaic system; (ii) high power elements (refrigerators, air conditioners) are supplied by the generator set; (iii) the autonomy of the photovoltaic system is 5 days.

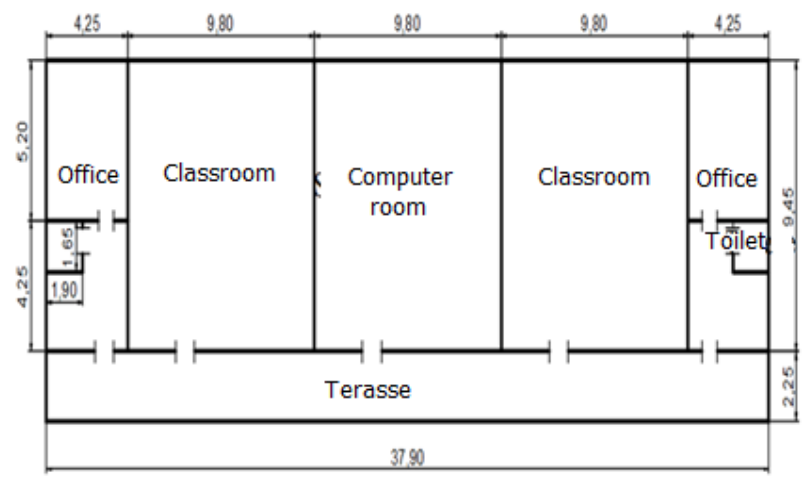

Figure 1.a Ground plan of the building.

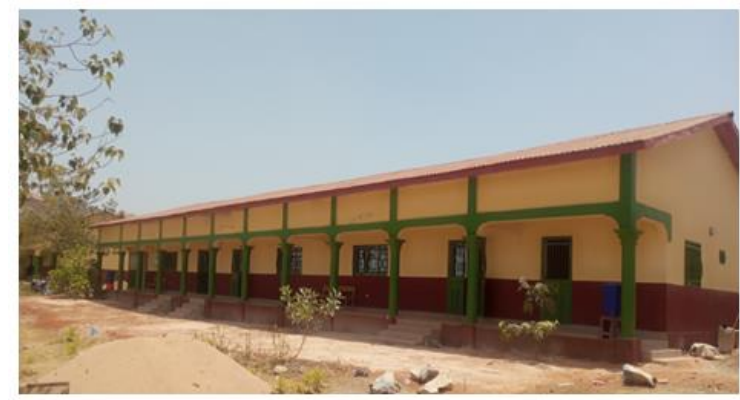

Figure 1.b Photo of the building.

\subsection{Method}

\section{a) Balance of electrical charges}

The building's electrical load balance is given in Table 1.

\section{b) Sizing and configuration of the photovoltaic field}

The sizing of a photovoltaic field is the search for a balance between the satisfaction of the expressed energy demand and the power to be installed (formula 1).

$$
\mathrm{Ep}=\frac{\mathrm{Ec}}{\mathrm{K}}
$$

For systems with battery bank, the $\mathrm{K}$ coefficient is between 0.55 and 0.75 . The peak power $(\mathrm{Pc})$ of the panels to be installed depends on the irradiation of the installation area. It is calculated by formula 2 [14].

$$
\mathrm{Pc}=\frac{\mathrm{Ec}}{\mathrm{K} . \mathrm{Ir}}
$$

With:

Pc : Peak power in peak Watt (Wp), Ep: Energy produced per day $(\mathrm{Wh} / \mathrm{d}), \mathrm{Ir}=4.16 \mathrm{kWh} / \mathrm{m}^{2} . \mathrm{d}$ : Average daily irradiation of the worst month in the city of Mamou (4.16 $\mathrm{kWh} / \mathrm{m}^{2}$.day) [14]. 
Table 1. Balance of powers and energies

\begin{tabular}{|l|c|c|c|}
\hline \multicolumn{1}{|c|}{ Designation } & Amount & Power (W) & Operating time (h/d) \\
\hline LED strip 120 cm T8 & 30 & 36 & 12 \\
\hline Energy saving lamps & 10 & 7 & 12 \\
\hline Computer & 50 & 200 & 12 \\
\hline Printer & 4 & 60 & 6 \\
\hline Refrigerators & 2 & 300 & 12 \\
\hline Air conditioners & 2 & 930 & 12 \\
\hline Air conditioners & 3 & 2500 & 12 \\
\hline
\end{tabular}

\section{c) Panel type and connection mode}

The solar panels chosen are of the type Cip-60235, Сip-60-250, Сip-60-260, Сip-60-270, HR-240W, HR-245W, HR-250W and HR-255W.

The branch numbers associated in parallel and series are given by formulas 3 and 4 [15].

$$
\mathrm{N}_{b p}=\frac{\mathrm{P}_{\mathrm{C}}}{\mathrm{I}_{\mathrm{m}} \cdot \mathrm{U}_{\mathrm{s}}} \quad \text { and } \quad \mathrm{N}_{b s}=\frac{\mathrm{U}_{\mathrm{s}}}{\mathrm{U}_{\mathrm{m}}}
$$

Where: Us $=48 \mathrm{~V}$ is the maximum voltage of the PV system. The total number of panels $(\mathrm{NP})$ is therefore determined by formula 5 .

$$
\mathrm{N}_{\mathrm{P}}=\mathrm{N}_{\mathrm{bp}} \times \mathrm{N}_{\mathrm{bs}}
$$

The peak power of the field to be installed (PCI) is determined by expression 6 .

$$
\mathrm{P}_{\mathrm{CI}}=\mathrm{N}_{\mathrm{P}} \times \mathrm{U}_{\mathrm{m}} \cdot \mathrm{I}_{\mathrm{m}}
$$

The type of solar panel that would be more suitable for the PV system is one which, for an immediately higher installed peak power.

\section{d) Inverter power}

The efficiency of the inverter is the ratio of the output power $(A C)$ to the input power (DC is calculated see formula 7.

$$
\eta=\frac{\mathrm{P}_{\mathrm{AC}}}{\mathrm{P}_{\mathrm{CC}}}
$$

The power of the inverter to be installed is determined by formula 8 [14].

$$
\mathrm{P}_{\text {ond }}=\frac{(1,2 \text { à } 1,3) \times \mathrm{E}_{\mathrm{C}}}{\eta_{\text {ond }}}
$$

Where: $\eta_{\text {ond }}$ is the efficiency of the inverter. Manufacturers generally indicate that the maximum efficiency is $95 \%$.

To adapt the fleet of inverters to the photovoltaic field, it is necessary to assess:

- The number of panels to group per inverter, determined by formula 9 .

$$
\mathrm{N}_{\mathrm{P} / \mathrm{ond}}=\frac{\mathrm{U}_{\mathrm{b}} \times \mathrm{I}_{\mathrm{m}}}{\mathrm{U}_{\mathrm{m}} \times \mathrm{I}_{\mathrm{m}}}
$$

The number of inverters in the park, determined by formula 10.

$$
\mathrm{N}_{\text {ond. }}=\frac{\mathrm{Np}}{\mathrm{N}_{\mathrm{P} / \text { ond }}}
$$

\section{e) Controller configuration}

The current delivered by the photovoltaic field must not exceed a certain limit imposed by the regulator. The value must $1,25 \times I c c$ therefore be lower than the nominal current of the regulator $1,25 \times \mathrm{Icc}<\mathrm{I}_{\mathrm{NR}}$ ) [16]. Thus, the no-load voltage increased by value $N_{b s} \times U_{c o}$ must be lower than the maximum admissible voltage of the regulator $\left(\mathrm{U}_{\mathrm{mar}}\right)$, i.e. $\mathrm{N}_{\mathrm{bs}} \times \mathrm{U}_{\mathrm{co}}<\mathrm{U}_{\mathrm{mar}}$.

The voltage of the battery bank must conform to the configuration of the regulator $\left(\mathrm{U}_{\mathrm{b}} \leq \mathrm{U}_{\mathrm{m}}\right)$.

\section{f) Sizing and configuration of the battery bank}

The sizing of the battery results from the following two technical choices: choice of battery voltage and choice of battery capacity. Thus, the respect of these electrical needs is formalized by relation 11 [14].

$$
\mathrm{C}_{\mathrm{t}_{\mathrm{d}}} \geq \frac{\mathrm{N}_{\mathrm{j}} \times \mathrm{E}_{\mathrm{c}}}{\mathrm{P}_{\mathrm{d}} \times \mathrm{R}_{\mathrm{b} .} \times \mathrm{U}_{\mathrm{b}}}
$$

With: $\mathrm{C}$ : battery capacity in (Ah); td $=\mathrm{Nj} \times 24$ : battery discharge time; Ec: Energy consumed per day $(\mathrm{Wh} / \mathrm{j}) ; \mathrm{Nj}$ : Number of days of autonomy ; $P_{d}$ : maximum allowable discharge rate ( 0.8 for lead batteries); $R_{b}$ : Efficiency of the battery charge and discharge cycles $(90 \%) ; U_{b}$ : battery voltage. The number of branches of the batteries in parallel is determined by formula 12 .

$$
\mathrm{N}_{b p}=\frac{\mathrm{C}_{\mathrm{td}}}{\mathrm{C}_{\mathrm{n}}}
$$

Where: $C_{n}$ is the nominal capacity battery. Depending on the field of application of the battery, a nominal value is defined [9]. If the voltage of a standard battery is (Ua) and the system is operating under voltage 
$\left(U_{b}\right)$, the number of batteries coupled in series is determined by formula 13 .

$$
\mathrm{N}_{\mathrm{bs}}=\frac{\mathrm{U}_{\mathrm{b}}}{\mathrm{U}_{\mathrm{a}}}
$$

The total number of batteries is thus given by formula 14.

$$
\mathrm{N}_{\mathrm{tb}}=\mathrm{N}_{\mathrm{bs}} \times \mathrm{N}_{\mathrm{bp}}
$$

\section{g) Sizing and choice of cables}

We determine the section of the cables causing the voltage drop between the panels and the invertercharger, but also between the batteries and the invertercharger (formula 15) [14].

$$
\mathrm{S}=\frac{2 \times \rho \times \mathrm{L}}{\mathrm{R}_{\mathrm{m}}}
$$

With: $\rho$ in $\Omega$. $\mathrm{m}$ the Resistivity of the conductive material in normal service. The resistivity of the conductor is given by the manufacturer. It depends on the material and the temperature.

\section{h) Battery voltage and voltage drop in a cable}

The allowable voltage drop in a cable is determined by formula 16 [8].

$$
\varepsilon=\frac{\rho \times \mathrm{L} \times \mathrm{I}}{S \times \mathrm{U}_{\mathrm{b}}}
$$

This voltage drop in a cable must not exceed $2 \%$, i.e. $\leq$ 0.02 .

\section{Results and discussions}

The various results obtained during this study relate to: the solar irradiation of the site, the balance of the electrical charges, the configuration of the photovoltaic field, the configuration of the invertercharger park and the electrical diagram of the system.

\subsection{Solar irradiation of the site}

The curves in Figure 2 show the variation in solar irradiation at the site on the horizontal and inclined plane. $\checkmark \quad \rho 0=1.851 \times 10-8 \Omega \mathrm{m}$ : for a copper conductor under $20^{\circ} \mathrm{C}$;

$\checkmark \rho 0=2.941 \times 10-8 \Omega \mathrm{m}$ : for an aluminum conductor at $20^{\circ} \mathrm{C}$.

The maximum voltage drop between panels junction box - inverter - battery is:

$$
\Delta \mathrm{U}=0,02 \times \mathrm{U}_{\mathrm{b}}
$$

The calculation parameters of the section of the cables are given in table 2 .

As the system operates throughout the school year (October - June), we choose the month of the season when the maximum sunshine is the most unfavorable (June). Figure 2 shows that in June the average number of maximum sun hours is the lowest for the $15^{\circ}$ south slope, i.e. 4.16 hours of sun per day at $1000 \mathrm{~W} / \mathrm{m}^{2}$, for irradiation $\left(\mathrm{Ir}=4.16 \mathrm{kWh} / \mathrm{m}^{2} . \mathrm{j}\right)$.

\subsection{Assessment of the building's electrical loads}

The building's electrical load balance is represented by the diagrams in figures 3.a and 3.b.

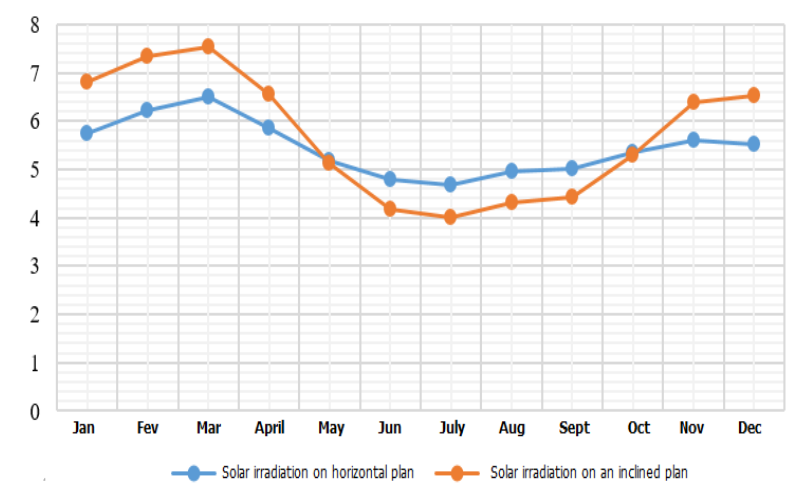

Figure 2. Solar irradiation of the site on the horizontal and inclined plane.

Table 2. Calculation parameters for the cross-section of the cables

\begin{tabular}{|l|c|c|c|c|}
\hline Distance & Current & $\begin{array}{c}\text { Maximum } \\
\text { resistance }\end{array}$ & $\begin{array}{c}\text { Cable } \\
\text { length }\end{array}$ & $\begin{array}{c}\text { Conductor } \\
\text { section }\end{array}$ \\
\hline $\begin{array}{l}\text { Between the panels and } \\
\text { the junction box }\end{array}$ & $\mathrm{I}=\frac{2 \times \mathrm{P}_{\mathrm{CP}}}{\mathrm{U}_{\mathrm{co}}}$ & $\mathrm{R}_{\mathrm{m}}=\frac{\Delta \mathrm{U}}{\mathrm{I}}$ & $\mathrm{L}_{\mathrm{P}-\mathrm{B}}$ & $\mathrm{S}=\frac{\rho \times 2 \times \mathrm{L}_{\mathrm{P}-\mathrm{B}}}{\mathrm{R}_{\mathrm{m}}}$ \\
\hline $\begin{array}{l}\text { Between the junction box } \\
\text { and the inverter }\end{array}$ & $\mathrm{I}=\frac{\left(\mathrm{N}_{\mathrm{P} / \mathrm{ond}}\right)_{\mathrm{A}} \times \mathrm{P}_{\mathrm{CP}}}{\mathrm{U}_{\mathrm{co}}}$ & $\mathrm{R}_{\mathrm{m}}=\frac{\Delta \mathrm{U}}{\mathrm{I}}$ & $\mathrm{L}_{\mathrm{B}-\text { Ond }}$ & $\mathrm{S}=\frac{\rho \times 2 \times \mathrm{L}_{\text {ba-ond }}}{\mathrm{R}_{\mathrm{m}}}$ \\
\hline $\begin{array}{l}\text { Between the inverter and } \\
\text { the battery bank }\end{array}$ & $\mathrm{I}=\frac{\mathrm{P}_{\text {Nond }}}{\mathrm{U}_{\text {bat. }}}$ & $\mathrm{R}_{\mathrm{m}}=\frac{\Delta \mathrm{U}}{\mathrm{I}}$ & $\mathrm{L}_{\mathrm{o}-\mathrm{b}}$ & $\mathrm{S}=\frac{\rho \times 2 \times \mathrm{L}_{\text {ond-ba }}}{\mathrm{R}_{\mathrm{m}}}$ \\
\hline
\end{tabular}




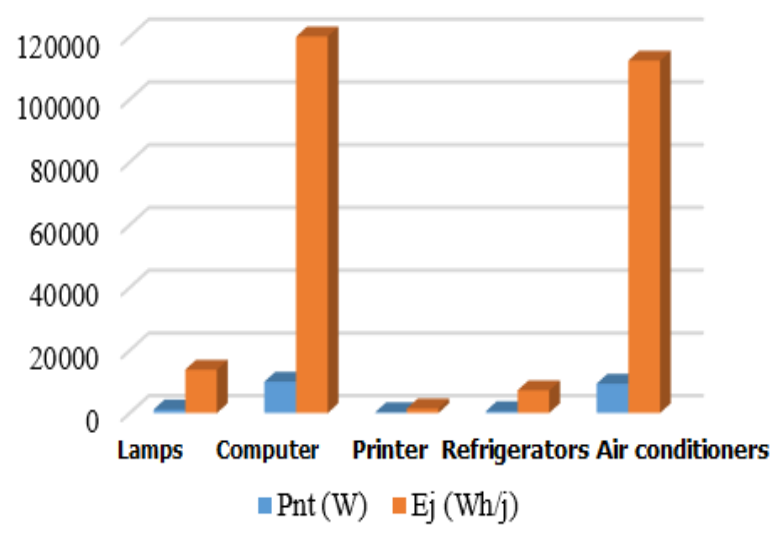

Figure 3.a Nominal powers and energies of all loads.

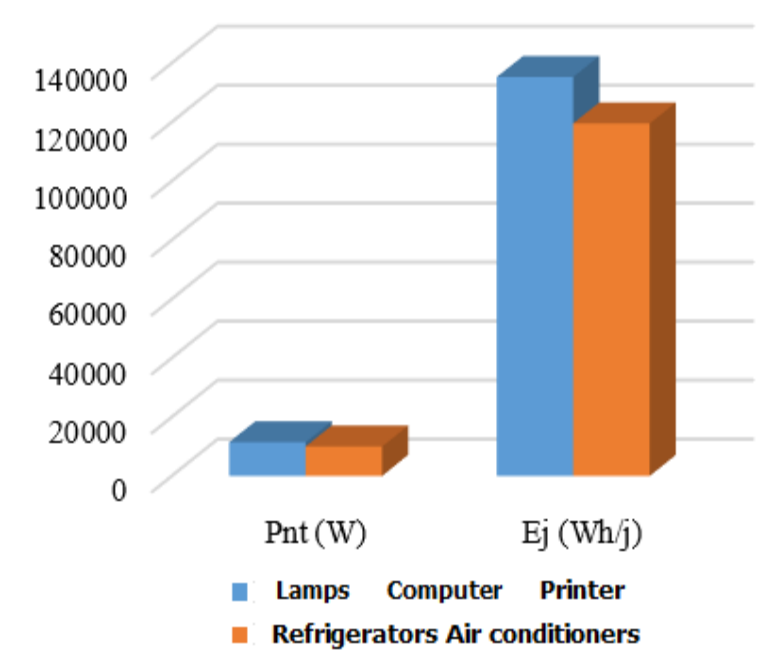

Figure 3.b Nominal powers and energies according to the types of loads.

The different loads are made up of: lamps, computer, printer, refrigerators and air conditioners. The unit powers of these loads vary from 7 to $2500 \mathrm{~W}$, depending on the elements. All of these loads operate 12 hours a day except printers which operate 6 hours a day. The diagram (figure 3.a) shows that the total nominal power of the 50 computers of nominal unit power of $200 \mathrm{~W}$ each is $10000 \mathrm{~W} / \mathrm{d}$, with a daily energy of $120000 \mathrm{Wh} / \mathrm{d}$. These consumers are followed respectively: air conditioners of two types, therefore 2 of $300 \mathrm{~W}$ and 3 of $2500 \mathrm{~W}$ for a total daily energy of 112320 $\mathrm{Wh} / \mathrm{d}$; Lamps of two types ( 30 of $36 \mathrm{~W}$ and 10 of $7 \mathrm{~W}$ ) for a daily energy of $13800 \mathrm{Wh} / \mathrm{d}$; two Refrigerators of $300 \mathrm{~W}$ each) for a daily energy of $7200 \mathrm{Wh} / \mathrm{d}$ and four 60 $\mathrm{W}$ Printers for a daily energy of $1440 \mathrm{Wh} / \mathrm{d}$. Thus, all of this equipment has a total daily charge of $254760 \mathrm{Wh} / \mathrm{d}$. These different devices have been grouped into two groups of consumers (figure $3 . b$ ):

- Lamps, computers and Printers constitute the first group, they have a total daily load of $135240 \mathrm{Wh}$ $\mathrm{d}$, or $53.09 \%$ of the total system loads, this group is powered by the photovoltaic field.

- The Refrigerators and Air Conditioners constitute the second group, they have a total daily load of $119,520 \mathrm{Wh} / \mathrm{d}$, or $46.91 \%$ of the total load of the system, this group will be supplied by the generator.

\subsection{Sizing of the photovoltaic field}

During this study, the Cip-60-270 type solar panels were chosen, taking into account their performance. The PV array has a peak power of $59435.420 \mathrm{Wp}$. It is composed of 220 panels including 02 panels in series in 110 branches in parallel.

\subsection{Inverter-chargers}

The type of inverter chosen to cover the need for an alternating power of $195346.67 \mathrm{~W}$, is the C4000-48 with a continuous nominal power of $3500 \mathrm{~W}$, each inverter will be connected to a group of 04 panels, i.e. two (02) panels connected in series in two (02) branches in parallel. Thus a total of $62 \mathrm{C} 4000-48$ Inverters would be necessary to achieve a corresponding total continuous power of $217000 \mathrm{Wp}$.

\subsection{Battery Park}

The battery bank with a total capacity of 19565.972 Ah is made up of multiples of $401.2 \mathrm{~V}$ NickelCadmium accumulators in series in 140 batteries connected in parallel. The total discharge current corresponding to a discharge time of 120 hours is 163.050 A. Each $1.2 \mathrm{~V}$ battery has a capacity of under a current of $1.1666 \mathrm{~A}$.

\subsection{Choice of cables}

For the purpose of checking the voltage of the battery bank, the voltage drop in the cables must not exceed $2 \%$, i.e. $\varepsilon \leq 0.02$, with $\mathrm{U}_{\mathrm{b}} \geq 32.39 \mathrm{~V}$. We can therefore conclude that the choice of a battery bank voltage equal to $48 \mathrm{~V}$ is correct. With this voltage of 48 $\mathrm{V}$, the voltage drop (in the cable between the battery bank and the inverter will be equal to $\varepsilon=$ $(0.60735938) /\left(U_{b}\right)=0.01265332$. We can therefore conclude that the voltage drop chosen is correct, because the condition $0,01<\varepsilon<0,02$ is met.

\subsection{Electrical diagram}

The electrical diagram of the system installation (Figures 4) shows the different panel connection modes, the battery coupling and the connection to the inverter. 


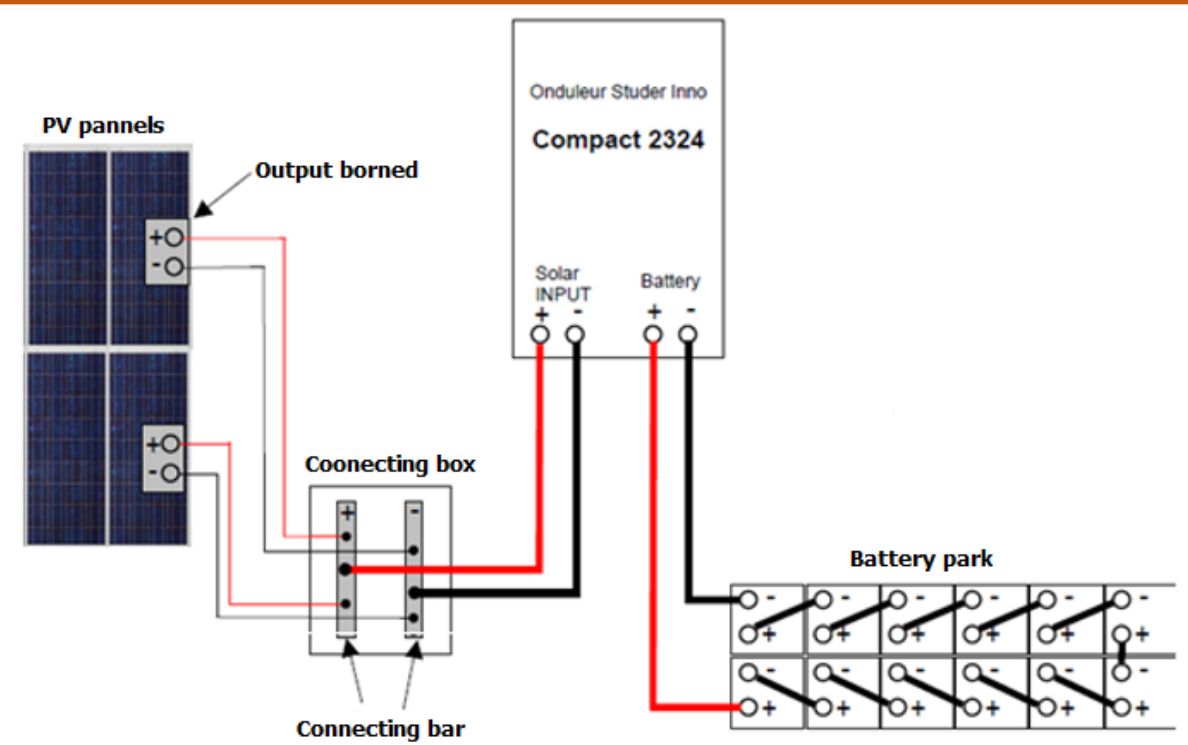

\section{Conclusion}

Hybrid energy systems are the most promising for the use of renewable energies. In Africa, where solar energy potential is high, it is important to promote the systematic substitution of conventional energy sources which are becoming more and more restrictive with regard to the cost of operation and operation. In this work, we presented the different configurations of PV/Generator hybrid energy systems with and or without isolated site storage.

\section{References}

[1] Heuraux Christine, Formation aux métiers de l'électricité: un projet pilote en Afrique de l'Ouest au service de l'électrification rurale, EDF, 21 et 23 mars Ouagadougou (2011).

[2] Brahim Abdallah Brahim, Etude des différentes configurations des systèmes d'énergie hybride PV/ Diesel et de leur impact sur le coût de production d'électricité. Mémoire de Master, Ouagadougou, (2013) 56p

[3] M. A. Sendhil, S. Balasubramanian, and G. Arunkumar, Current Status of Research on Hybrid Power Generation Systems, Research Journal of Applied Sciences, Engineering and Technology, 8(14) (2014) 1684-1690. [DOI]

[4] Ansoumane SAKOUVOGUI, Evaluation du potentiel énergétique des déjections animales et des émissions de méthane en vue de la réalisation et de l'expérimentation d'un digesteur à
Mamou (République de Guinée). Thèse de doctorat, Université Gamal Abdel Nasser de Conakry-Guinée, (2019), 125p.

[5] M. Asif et T. Muneer, Energy supply, its demand and security issues for developed and emerging economies, Renewable and Sustainable Energy Reviews, 11 (2007) 1388-1413.

[6] T.R. Mtshali, G. Coppez, S. Chowdhury and S.P. Chowdhury, Simulation and Modelling of PV-Wind-Battery Hybrid Power System, IEEE Power and Energy Society General Meeting, 2011, pp. 1-7. [DOI]

[7] Abdoul Karim TRAORE, Gestion d'un système autonome hybride photovoltaïque éolien pour applications agricoles un1versité du Quebec, Mémoire de Maîtrise en Génie Electrique, (2016) 134p.

[8] L. Bemal-Agustin and R. Dufo-Lapez, Simulation and optimization of standalone hybrid renewable energy systems, Renewable and Sustainable Energy Reviews, 13(8) (2009) 21112118. [DOI]

[9] P. Bajpai and V. Dash, Hybrid renewable energy systems for power generation in stand-alone applications: A review, Renewable and Sustainable Energy Reviews, 16(5) (2012) 2926-2939. [DOI]

[10] C. Gopal, M. Mohanraj, P. Chandramohan, and P. Chandrasekar, Renewable energy source water pumping 
systems - A literature review, Renewable and Sustainable Energy Reviews, 25 (2013), 351-370. [DOI]

[11] M. Elhassan, M. Fauzi, K. Sopian and A. A. Abass, Design and Performance of Photovoltaic power System as a Renewable Energy Source for Residential in Khartoum, International Journal of the Physical Sciences, 7(25) (2012) 40364042.

[12] W.D. Kellogg, M.H. Nehrir, G. Venkataramanan and V. Gerez, Generation Unit Sizing FEDDAOUI Omar, Contribution à l'Etude des Systèmes Hybrides de Génération: Application aux Energies Renouvelables, Mémoire de Magister, Algérie, (2014) 130p.

[13] Ansoumane SAKOUVOGUI, Mamadou Foula BARRY, Younoussa Moussa BALDE, Cellou KANTE and Mamby KEITA, Sizing, Construction and Experimentation of a Chinese Type Digester in Mamou Prefecture (Republic of Guinea), International Journal of Engineering Science and Computing, 8(9) (2018) 18926-18933

[14] D. Amadou, K. Cellou, S. Ansoumane, B. Saïdou and K. Mamby, Study and Design of a Photovoltaic Pumping System in the Madinah Sector at Dogomet Prefecture Dabola (Guinea), European Modern Studies Journal, 4(1) (2020) 130-137.

[15] Daniel YAMEGUEU, Experimentation et optimisation d'un prototype de central hybride solaire PV/Diesel sans batteries de stockage: Validation du concept Flexy Energ. These de doctorat Laboratoire Energy solaire et Economie d'Energie et Laboratoire Procédés, Matériaux et Energie Solaire (2012).

[16] W.D. Kellogg, M.H. Nehrir, G. Venkataramanan and V. Gerez, Generation Unit Sizing and Cost Analysis for Stand-Alone Wind, Photovoltaic, and Hybrid Wind PV Systems, IEEE Transactions on Energy Conversion, 13(1) (1998) 70-75. [DOI]

\section{Acknowledgments}

This research work is the result of cooperation between the Applied Energy Education and Research Laboratory of the Physics Department of the Faculty of Sciences of the Gamal Abdel Nasser University of Conakry and the Energy Department of the Higher Institute of Mamou Technology, Guinea. This research could not have been carried out without the support of these institutions and of certain scientific personalities to whom we would like to express our deep gratitude.

\section{Funding}

No funding was received for conducting this study.

\section{Conflict of interest}

The authors have no conflicts of interest to declare that they are relevant to the content of this article.

\section{About the License}

(C) The author(s) 2021. The text of this article is open access and licensed under a Creative Commons Attribution 4.0 International License 